\title{
The use of fetal bovine serum as delivery vehicle to improve the uptake and stability of lycopene in cell culture studies
}

\author{
Chen-Yu Lin, Chin-Shiu Huang and Miao-Lin $\mathrm{Hu}^{*}$ \\ Department of Food Science and Biotechnology, National Chung Hsing University, Taichung 40227, Taiwan, ROC \\ (Received 2 October 2006 - Revised 18 December 2006 - Accepted 15 January 2007)
}

Tetrahydrofuran (THF) has commonly been used to deliver carotenoids to cells but the use of THF is associated with cytotoxicity and low uptake efficiency of carotenoids. Here, we used fetal bovine serum (FBS) as the delivery vehicle for lycopene in comparison with THF, THF containing $0.0025 \%$ butylated hydroxytoluene (THF/BHT), methyl- $\beta$-cyclodextrin (M- $\beta$-CD) and micelles in two human prostate cancer cell lines, DU145 and PC-3. Lycopene (10 mM) solubilized in THF/BHT and then diluted in FBS at ratios of 5 and 10 gave the highest lycopene uptake in DU145 cells. Using a dilution factor of 10 , we found that lycopene $(10 \mu \mathrm{M})$ carried in FBS in a cell-free system led to significantly less loss of lycopene than in THF, THF/BHT and M- $\beta-C D$ within $24 \mathrm{~h}$ of incubation. Lycopene solubilized in micelles was more stable than that in FBS within $24 \mathrm{~h}$, but the micelle itself led to marked cytotoxicity to DU145 cells. Lycopene at $10 \mu \mathrm{M}$ in FBS led to significantly higher uptake of lycopene in both cell lines than that in THF, THF/BHT or M- $\beta-C D$ within $24 \mathrm{~h}$ of incubation. When FBS was replaced with lipoprotein-deficient serum, the uptake of lycopene by DU145 cells was markedly decreased and was not significantly different from that of THF or THF/BHT. These results demonstrate that FBS is superior to THF, THF/BHT, M- $\beta-\mathrm{CD}$ and micelles as a delivery vehicle for lycopene in prostate cell lines and that the lipoprotein of FBS is likely responsible for the improved stability and cellular uptake of lycopene.

Cellular uptake: Delivery vehicles: Fetal bovine serum: Lycopene

Carotenoids are a class of natural pigments that possess antioxidant activities both in vitro and in vivo (Stahl \& Sies, 1996; Clinton, 1998; Bramley, 2000). Among the more than 600 carotenoids found in nature, $\beta$-carotene and lycopene are the two most abundant carotenoids present in the human body (Sies \& Stahl, 2003) Studies have suggested that higher intakes of lycopene are associated with a reduced risk of several types of cancer, such as prostate cancer and hepatoma (Stahl \& Sies, 1996; Clinton, 1998; Kotake-Nara et al. 2001). Cell culture studies are useful for elucidating the mechanisms of action of lycopene, and tetrahydrofuran (THF) has commonly been used to deliver lycopene to cells (Bertram et al. 1991; Conney et al. 1993; Huang et al. 2005; Tang et al. 2005; Yeh et al. 2005). However, the use of THF as the solvent for carotenoids including lycopene has repeatedly been questioned because of its disadvantages in cell culture studies (Gross et al. 1997; Wang et al. 2004; Rodriguez et al. 2005). For instance, THF oxidizes readily in culture media, which can lead to instability of lycopene and result in cytotoxicity (Xu et al. 1999; Williams et al. 2000; Shahrzad et al. 2002; Hurst et al. 2004; O'Sullivan et al. 2004) so that the final concentration of THF must be below $0.5 \%$ (Huang et al. 2005; Tang et al. 2005; Yeh et al. 2005). In addition, lycopene dissolved in THF has low cellular association and high standard deviation
(Shahrzad et al. 2002). Therefore, attempts have been made by using vehicles other than THF for delivering lycopene to cells including dimethyl sulphoxide (DMSO), cyclodextrin, lipoprotein, micelle and beadlets (Martin et al. 1996, 1997; Stivala et al. 1996; Garrett et al. 1999; Pfitzner et al. 2000; Lancrajan et al. 2001; Da Violante et al. 2002; Gamer et al. 2002; Vertzoni et al. 2006). Each of these vehicles provides certain advantages but also suffers limitations such as cytotoxicity, poor solubility and crystallization in the medium (Stivala et al. 1996; Xu et al. 1999; Lancrajan et al. 2001; Shahrzad et al. 2002; O'Sullivan et al. 2004; Palozza et al. 2006). For example, DMSO has been used for delivering carotenoids into cells because it readily penetrates cell membranes and is relatively non-cytotoxic (Da Violante et al. 2002; Rodriguez et al. 2005). However, DMSO is also unstable and has low solubility for carotenoids (Gross et al. 1997). Indeed, the half-life of lycopene in aqueous/organic solvents is only $2 \mathrm{~h}$, which is inappropriate for the studies of carotenoids (Xu et al. 1999). The use of Tween 40 and Tween 80 to deliver phytochemicals including lycopene to cultured cells has been advocated (O'Sullivan et al. 2004), but the method is somewhat laborious and may require extra care to avoid oxidation of carotenoids, as it requires drying the solvent twice (under nitrogen) followed by filtration.

\footnotetext{
Abbreviations: BHT, butylated hydroxytoluene; DMEM, Dulbecco's modified Eagle's medium; FBS, fetal bovine serum; M- $\beta$-CD, methyl- $\beta$-cyclodextrin; THF, tetrahydrofuran.

*Corresponding author: Prof. Miao-Lin Hu, fax +886 4 22812363, email mlhuhu@dragon.nchu.edu.tw
} 
Several other vehicles for delivering carotenoids have been reported. For instance, cyclodextrin-complexed carotenoids have been shown to protect carotenoid from reactive oxygen species, but such complexes result in considerable decrease in antioxidant ability of the carotenoid (Polyakov et al. 2004). The water-dispersible carotenoid beadlets have been shown to be non-toxic and relatively stable to cultured cells (Shahrzad et al. 2002), but these beadlets are not commercially available. Another useful vehicle for delivering carotenoids into cells in vitro is micelles because, as reported by $\mathrm{Xu}$ et al. (1999), they are non-cytotoxic and can stabilize carotenes such as lycopene. However, Martin et al. (1997) have found that their micelle preparation does not stabilize carotenoids, and they have advocated the use of human lipoproteins for solubilizing and stabilizing carotenoids. Indeed, carotenoids including lycopene have been suggested to be transported by lipoprotein in man (Cardinault et al. 2005; Palozza et al. 2006). It is interesting to note that Williams et al. (2000) have used bovine serum from steer supplemented with $\beta$-carotene as a delivery vehicle in cell culture and have obtained satisfactory results, as compared to other vehicles.

In the present report, we made use of the fact that fetal bovine serum (FBS) contains lipoproteins, which may be a convenient and useful vehicle for delivering lycopene into cells in culture. To test this possibility, we solubilized lycopene in THF containing butylated hydroxytoluene (BHT), diluted the THF/BHT-lycopene mixture in FBS at different ratios, and selected an appropriate ratio for studying the stability and cellular uptake of lycopene in two prostate cancer cell lines. Although Martin et al. (2000) have used ethanol-THF to dissolve carotenoids and mixed them with FBS to deliver carotenoids into human aortic endothelial cells, they have not described the details, nor have they compared the method with other delivery vehicles for carotenoids. Here, we compared the FBS dilution method of lycopene with other solubilization vehicles for lycopene including THF, THF containing $0.0025 \%$ BHT (THF/ BHT), methyl- $\beta$-cyclodextrin (M- $\beta-\mathrm{CD})$ and micelles in cultured cells, and we measured the cytotoxicity of these delivery vehicles and the stability and cellular uptake of lycopene in these vehicles. We used two human prostate cancer cell lines, DU145 and PC-3, both of which are androgen-independent, because lycopene is most frequently reported to prevent prostate cancer (Kristal \& Cohen, 2000).

\section{Material and methods}

\section{Materials}

The human androgen-independent prostate cancer cell lines DU145 and PC-3 cells were purchased from the Food Industry Research and Development Institute, Taiwan. All chemicals used are of the highest grade. THF, THF containing $0.0025 \%$ BHT, and FBS were obtained from Merck (Darmstadt, Germany). Dulbecco's modified Eagle's medium (DMEM), non-essential amino acid, penicillin/streptomycin, sodium pyruvate and trypsin were from Gibco/BRL (Grand Island, NY, USA). Lycopene and lipoprotein-deficient serum were from Sigma (St Louis, MO, USA) and M- $\beta-C D$ was from Fluka (Steinheim, Switzerland).
Preparation of lycopene in various vehicles

Stock solutions of lycopene $(10 \mathrm{~mm})$ in THF or THF/BHT were freshly prepared before each experiment and were added to cell culture medium at a final concentration of $10 \mu \mathrm{M}$ which was determined to be between 9.0 and $10 \mu \mathrm{M}$ using HPLC as described later. To prepare the FBS-carried lycopene, we adopted the method of Martin et al. (2000) for preparing FBS-incorporated caroteneoids with some modification. Lycopene was first solubilized in THF/BHT to form a stock solution of $10 \mathrm{~mm}$-lycopene, which was then diluted with FBS at indicated ratios (1:4, 1:9, 1:19, 1:49). After vortexing for $1 \mathrm{~min}$, this $\mathrm{THF} / \mathrm{FBS}-$ lycopene preparation was added to cell culture to achieve a final concentration of $10 \mu \mathrm{M}$-lycopene in the culture medium. The final concentrations of THF and BHT in the culture medium were $0.1 \%$ and $0.0000025 \%$, respectively.

For solubilization of lycopene in M- $\beta-C D$, a quantity of $5 \mathrm{mg}$ lycopene was mixed with $1 \mathrm{ml}$ absolute ethanol $(5 \mathrm{mg} / \mathrm{ml})$, to which was added $0.5 \mathrm{~g} \mathrm{M}-\beta-\mathrm{CD} / \mathrm{ml}$ solution, and the organic solvent was removed under a stream of nitrogen in the dark. The residue $(1 \mathrm{~g})$ was re-dissolved in $2 \mathrm{ml}$ deionized water to achieve a final concentration of $9.3 \mathrm{~mm}$-lycopene and stored at $-80^{\circ} \mathrm{C}$.

The method for preparing micelle-solubilized lycopene (1 mM) was based on that reported by $\mathrm{Xu}$ et al. (1999). First, $13 \mu \mathrm{l} \mathrm{L- \alpha -phosphatidylcholine}(16 \cdot 7 \mu \mathrm{M}), 100 \mu \mathrm{l}$ oleic acid $(33 \cdot 3 \mu \mathrm{M}), 100 \mu \mathrm{l}$ monoolein $(100 \mu \mathrm{M})$ and $100 \mu \mathrm{l}$ $1 \mathrm{mM}$-lycopene (dissolved in THF/BHT) were combined, and the organic solvent was removed under nitrogen in the dark. Next, $10.76 \mathrm{mg}$ sodium taurocholate $(2 \mathrm{~mm})$ was added to $10 \mathrm{ml}$ of cell culture medium (DMEM) containing $10 \%$ FBS, and this mixture was used to dissolve the lycopene residue. The mixture was sonicated in a waterbath at room temperature for $15 \mathrm{~min}$ to form micelles containing lycopene and sterilized by passage through a $0.22 \mu \mathrm{m}$ filter.

\section{Cell culture and uptake of lycopene}

DU145 cells and PC-3 cells were grown in a $10 \mathrm{~cm}$ dish with $7 \mathrm{ml}$ DMEM containing $10 \%$ (v/v) FBS, $1 \%$ non-essential amino acid, $1 \%$ sodium pyruvate, $1 \%$ penicillin (10000 unit $/ \mathrm{ml})-$ streptomycin $(10 \mathrm{mg} / \mathrm{ml})$ and $0.37 \% \mathrm{NaHCO}_{3}(\mathrm{w} / \mathrm{v})$. The cells were incubated in a humidified atmosphere of $5 \% \mathrm{CO}_{2}$ and $95 \%$ air at $37^{\circ} \mathrm{C}$ and harvested at approximately $90 \%$ confluence $\left(10^{6}\right.$ cells/dish), after which the culture medium was decanted and replaced with fresh medium $(5 \mathrm{ml})$. Lycopene dissolved in THF, THF/BHT, M- $\beta-\mathrm{CD}$ or FBS was added to cells at a final concentration of $10 \mu \mathrm{M}$ (three Petri dishes/ group). The cells (approximately $10^{6}$ cells/dish) were incubated for $2,6,12$ and $24 \mathrm{~h}$ at $37^{\circ} \mathrm{C}$ in the dark. Cellular lycopene was extracted and analysed by HPLC, as described later.

\section{Stability of lycopene in cell-free medium}

The stability of the different lycopene solutions was measured under cell culture conditions in DMEM medium containing $10 \%$ (v/v) FBS, $1 \%$ non-essential amino acid, $1 \%$ sodium pyruvate, $1 \%$ penicillin (10000 unit $/ \mathrm{ml})$-streptomycin $(10 \mathrm{mg} / \mathrm{ml})$. The medium containing $10 \mu \mathrm{M}$ lycopene from different delivery vehicles was incubated at $37^{\circ} \mathrm{C}$ for $0,2,4$, 
6, 12 and $24 \mathrm{~h}$ in the dark, and the remaining lycopene was extracted and analysed by HPLC, as described later.

\section{Determination of lycopene in culture medium and in cells}

The cell-free culture medium $(1 \mathrm{ml})$ was added to $0.4 \mathrm{ml}$ mixture of hexane and absolute ethanol (2:1, v/v) and vortexed for $1 \mathrm{~min}$. The mixture was centrifuged at $1200 \mathrm{~g}$ for $4 \mathrm{~min}$, and the hexane layer, which contains lycopene, was transferred to an Eppendorf tube and stored at $-80^{\circ} \mathrm{C}$. The extracted lycopene was quantified by HPLC (Merck-Hitachi system, Darmstadt, Germany). The chromatography conditions were as follows: a C18 column, $250 \times 4.6 \mathrm{~mm}, 5 \mu \mathrm{m}$ was eluted at $1.5 \mathrm{ml} / \mathrm{min}$ with isocratic mobile phase (methanol-toluene, 75:25, v/v). The injection volume was $20 \mu \mathrm{l}$, and lycopene was monitored at $470 \mathrm{~nm}$ (Rundhaug et al. 1988).

For measurement of cellular lycopene, the culture medium was decanted and the cells were washed with PBS three times. The attached cells were scraped and resuspended with $1 \mathrm{ml}$ PBS. The cells were transferred from the dishes to centrifuge tubes and a $2 \mathrm{ml}$ mixture of hexane and absolute ethanol (2:1, v/v) was added (Rundhaug et al. 1988). After sonication in a water bath at room temperature for $1 \mathrm{~min}$, the mixture was centrifuged $(1200 \mathrm{~g}, 4 \mathrm{~min})$. The hexane layer was transferred to an Eppendorf tube and stored at $-80^{\circ} \mathrm{C}$ until assay for lycopene using HPLC, as described earlier.

\section{Determination of cellular uptake of lycopene}

The cellular uptake of lycopene is defined as the difference of total amounts of lycopene absorbed by the cells (determined at $37^{\circ} \mathrm{C}$ ) minus the amounts of lycopene adherent to the cell surface (determined at $4^{\circ} \mathrm{C}$ ) (Huang et al. 2007) for up to $24 \mathrm{~h}$. The amounts of lycopene adherent to the cell surface were found to be approximately $6 \%$ of the total lycopene. The percentage uptake efficiency of lycopene was calculated by the formula: $\left[\left(\mathrm{nmol}\right.\right.$ lycopene $/ 10^{6}$ cells $) /$ or $/$ or $/(\mathrm{nmol}$ lycopene/dish) $\times$ 100] (Williams et al. 2000), in which the numerator is the cellular uptake of lycopene, and the denominator is the amount of lycopene added to the medium $(10 \mu \mathrm{M}$ or $50 \mathrm{nmol}$ lycopene in $5 \mathrm{ml}$ medium per $10 \mathrm{ml}$ Petri dish).

\section{3-(4,5-Dimethylthiazol-2-yl)-2,5-diphenol tetrazolium bromide assay}

The cell viability of lycopene delivery vehicles was determined by microtitration assay using 3-(4,5-dimethylthiazol2-yl)-2,5-diphenol tetrazolium bromide. DU145 cells were seeded at a density of $5 \times 10^{4}$ cells per well in a twentyfour-well multititre plate in DMEM for $24 \mathrm{~h}$, and the culture medium was replaced with a delivery vehicle (THF, THF/ BHT, FBS or M- $\beta-C D)$ at $0 \cdot 1-1.0 \%$ THF or $M-\beta-C D$ and then incubated for $24 \mathrm{~h}$. 3-(4,5-Dimethylthiazol-2-yl)-2,5diphenol tetrazolium bromide $(0.25 \mathrm{mg} / \mathrm{ml})$ was added to each well and incubated for $1 \mathrm{~h}$, after which the liquid was removed, and dimethyl sulphoxide was added to dissolve the solid residue. The optical density at 570 and $492 \mathrm{~nm}$ of each well was then determined using a microplate reader (FLUOstar OPTIMA; BMG Labtechnologies, Germany).

\section{Statistical analysis}

Values are expressed as means and standard deviations and analysed by one-way ANOVA followed by Duncan's multiple range test for comparisons of group means. $P<0.05$ was considered significant.

\section{Results and discussion}

In the present study, we made use of the fact that FBS contains lipoproteins that are necessary for the transport of carotenoids (Cardinault et al. 2005; Palozza et al. 2006). Although FBS has been used to deliver carotenoids including lycopene to cultured cells (Martin et al. 2000), no experimental data on the stability and cellular uptake have been presented, and no comparisons of the FBS method with other delivery methods have been made. We first tested the appropriate dilution ratio of lycopene to FBS for delivering lycopene to DU145 cells. The stock solution of lycopene (10 mM in THF/BHT) was diluted with FBS at 5-, 10-, 20 - or 50 -fold. After incubation for $12 \mathrm{~h}$, we found that a dilution factor of 5 or 10 gave higher lycopene uptake than the dilution factor of 20 or 50 (Fig. 1). Because the uptake of lycopene by 10 -fold dilution was slightly higher than that by 5 -fold dilution, we adopted the 10-fold dilution for the studies of stability and cellular uptake of lycopene in comparison with other delivery vehicles for lycopene. For convenience, this THF/FBS delivery system is referred to as FBS.

Stability of lycopene in different delivery vehicles in cell-free systems

Fig. 2 shows the stability of lycopene in various vehicles in the cell-free system during incubation for $24 \mathrm{~h}$ at $37^{\circ} \mathrm{C}$ in the dark. Degradation of lycopene in different delivery vehicles increased with the incubation time, and the degradation rates of lycopene at $24 \mathrm{~h}$ were in the order: $\mathrm{THF}>\mathrm{THF} / \mathrm{BHT}>\mathrm{M}-\beta-\mathrm{CD}>$ FBS $>$ micelles. Approximately 80 and $50 \%$ lycopene remained for micelles and FBS, respectively, as the delivery

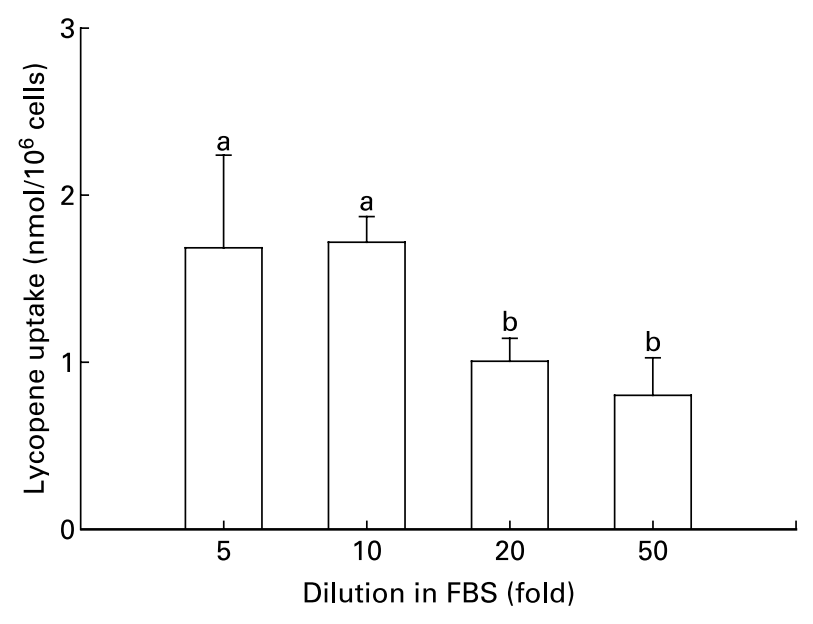

Fig. 1. Lycopene uptake by DU145 human prostate cancer cells incubated at $37^{\circ} \mathrm{C}$ for $12 \mathrm{~h}$ with lycopene (dissolved in tetrahydrofuran) diluted with fetal bovine serum (FBS) as delivery vehicle. Values are means with their standard deviations depicted by vertical bars $(n \geq 3)$. ${ }^{a, b}$ Mean values with unlike letters were significantly different $(P<0.05)$. 


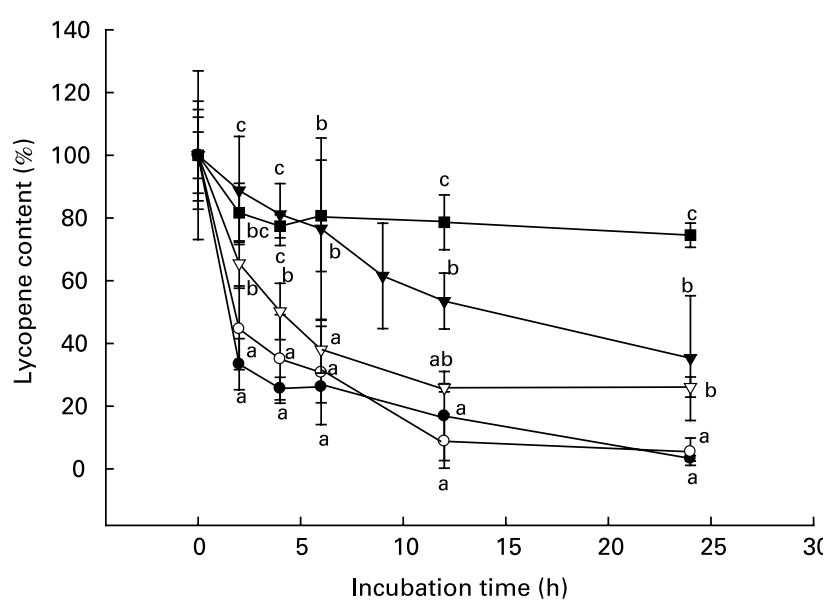

Fig. 2. Effects of tetrahydrofuran $(\bullet)$, tetrahydrofuran/butylated hydroxytoluene $(\bigcirc)$, fetal bovine serum $(\boldsymbol{\nabla})$, methyl- $\beta$-cyclodextrin $(\nabla)$ and micelles $(\boldsymbol{\square})$ on the stability of lycopene in cell-free systems. Incubations were carried out in the dark at $37^{\circ} \mathrm{C}$ for $2,4,6,12$ and $24 \mathrm{~h}$. Values are means with their standard deviations depicted by vertical bars. ${ }^{a, b, c}$ Mean values at the same time-point with unlike letters were significantly different $(P<0.05)$.

vehicle. This experiment shows that micelles can better stabilize lycopene than can other delivery vehicles used in the present study. It is unclear why Martin et al. (1997) reported that their micelle preparation does not stabilize carotenoids, since their method for preparing micelles is essentially the same as that used by us (Xu et al. 1999).

\section{Cytotoxicity of lycopene solubilized in various delivery vehicles}

Before we determined the uptake efficiency of lycopene, we examined the cytotoxicity of THF, THF/BHT, FBS,
M- $\beta-C D$ and micelles to prostate cancer cells in the absence of lycopene. In Fig. 3, the concentrations $(0 \cdot 1$ and $1.0 \%)$ of THF, THF/BHT and FBS referred to their solvent (THF). $M-\beta-C D$ and micelles referred to the vehicle itself, as both $M-\beta-C D$ and micelles were dried and re-suspended in deionized water $(M-\beta-C D)$ or the culture medium DMEM (micelles) before adding to the cells. We found that FBS (containing 0.1 or $1.0 \% \mathrm{THF}$ ) and M- $\beta-\mathrm{CD}$ were not cytotoxic to the cells incubated for $24 \mathrm{~h}$, whereas THF and THF/BHT at $1.0 \%$ (but not $0.1 \%$ ) caused a significant decrease in cell viability. Unexpectedly, the micellar preparation caused strong cytotoxicity to DU145 cells, and this effect was already evident at $2 \mathrm{~h}$ of incubation. We also observed cytotoxicity in PC-3 cells induced by micelles, but we only focused on DU145 because the uptake of lycopene in FBS was somewhat higher in DU145 cells than in PC-3 cells.

It is unclear why the micellar preparation (in DMEM) was cytotoxic, but it might be related to the fatty acids (e.g. phosphatidylcholine) contained in the micelles, which could undergo oxidation in cell culture medium. It is noteworthy that cell culture studies are normally carried out under abnormal conditions known as 'culture shock', where cells are exposed to high oxygen tension and to free metal ions in the medium (Halliwell, 2003). As a result of the cytotoxicity, we did not further study the uptake of lycopene by micelles.

\section{Cellular uptake of lycopene in different delivery vehicles}

Lycopene delivered by FBS achieved a higher cellular uptake than lycopene by other delivery vehicles during the $24 \mathrm{~h}$ incubation in both DU145 cells (Table 1) and PC-3 cells (Table 2). At $12 \mathrm{~h}$ of incubation, lycopene uptake in DU145 cells

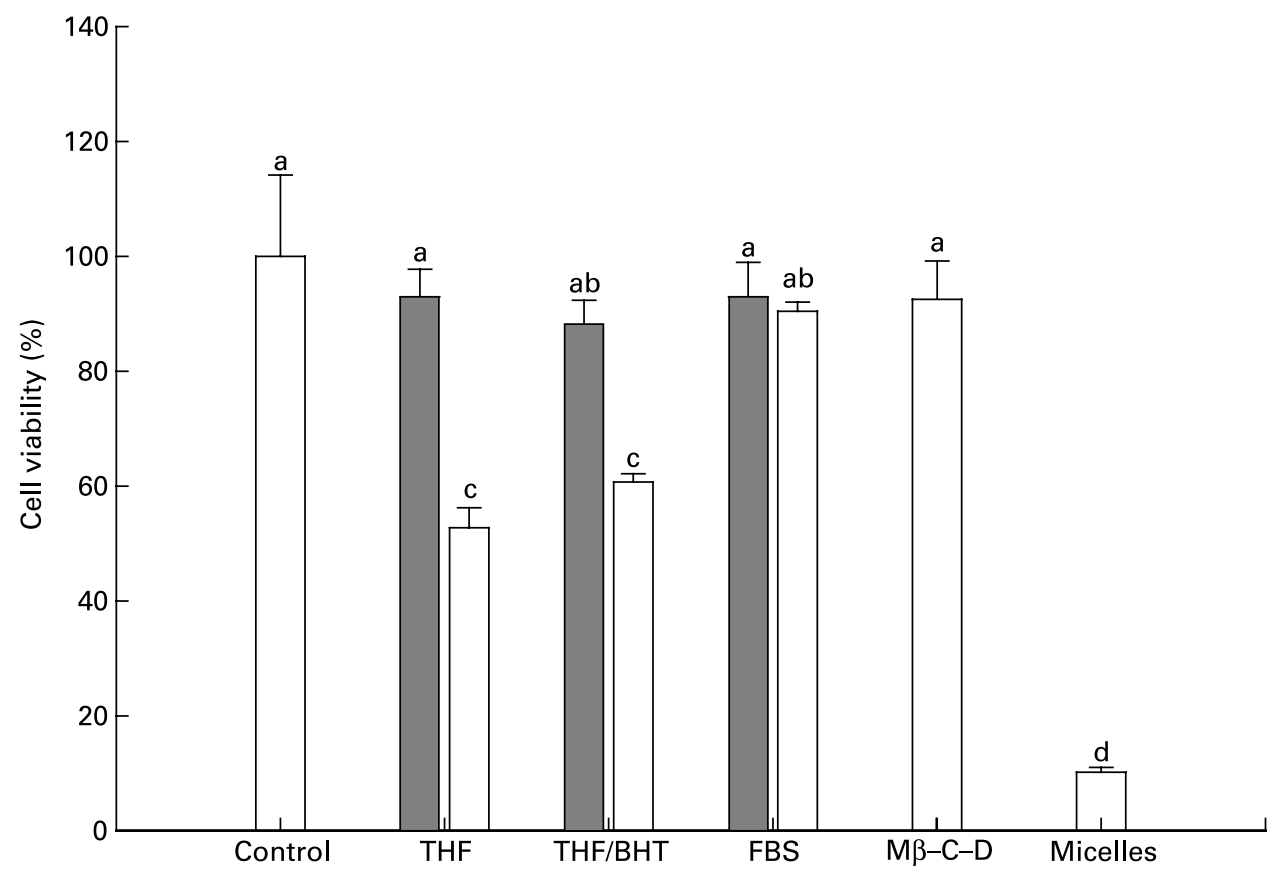

Fig. 3. Cell viability of DU145 cells incubated at $37^{\circ} \mathrm{C}$ for $24 \mathrm{~h}$ with tetrahydrofuran (THF), THF/butylated hydroxytoluene (THF/BHT), fetal bovine serum (FBS), methyl- $\beta$-cyclodextrin (M- $\beta-C D)$ and micelles. For THF, THF/BHT and FBS, two levels were used $(\square, 0.1 \%$; $\square$, $1.0 \%$ ), which referred to their solvent concentration (THF). M- $\beta-C D$ and the micellar preparation referred to the vehicle itself, since both vehicles were dried and re-suspended in deionized water and the culture medium (Dulbecco's modified Eagle's medium), respectively, before adding to the cells. Values are means with their standard deviations depicted by vertical bars. ${ }^{a, b, c, d}$ Mean values with unlike letters were significantly different $(P<0.05)$. 
Table 1. Uptake of lycopene (nmol/ $10^{6}$ cells) delivered to DU145 cells by tetrahydrofuran (THF), THF/butylated hydroxytoluene (BHT), fetal bovine serum (FBS) and methyl- $\beta$-cyclodextrin (M- $\beta-C D)$ for 2, 6, 12 and $24 \mathrm{~h}$

(Mean values and standard deviations)

\begin{tabular}{|c|c|c|c|c|c|c|c|c|}
\hline \multirow[b]{3}{*}{ Delivery methods } & \multicolumn{8}{|c|}{ Incubation time (h) } \\
\hline & \multicolumn{2}{|c|}{2} & \multicolumn{2}{|c|}{6} & \multicolumn{2}{|c|}{12} & \multicolumn{2}{|c|}{24} \\
\hline & Mean & SD & Mean & SD & Mean & SD & Mean & SD \\
\hline THF & $0.10^{\mathrm{b}}$ & 0.02 & $0.15^{\mathrm{a}}$ & 0.06 & $0.90^{\mathrm{b}}$ & 0.43 & $0.09^{b}$ & 0.04 \\
\hline THF/BHT & $0.14^{\mathrm{ab}}$ & 0.03 & $0.18^{a}$ & 0.03 & $1 \cdot 12^{\mathrm{b}}$ & 0.32 & $0.12^{b}$ & 0.04 \\
\hline FBS & $0 \cdot 18^{a}$ & 0.04 & $0.27^{a}$ & 0.13 & $1.72^{\mathrm{a}}$ & 0.29 & $0.37^{a}$ & 0.15 \\
\hline$M-\beta-C D$ & - & & - & & $1 \cdot 18^{b}$ & 0.01 & - & \\
\hline
\end{tabular}

a,b Mean values within a column with unlike superscript letters were significantly different $(P<0.05)$.

Table 2. Uptake of lycopene ( $\mathrm{nmol} / 10^{6}$ cells) delivered to PC-3 cells by tetrahydrofuran (THF), THF/butylated hydroxytoluene (BHT), fetal bovine serum (FBS) and methyl- $\beta$-cyclodextrin (M- $\beta-C D)$ for 2, 6, 12 and $24 \mathrm{~h}$

(Mean values and standard deviations)

\begin{tabular}{|c|c|c|c|c|c|c|c|c|}
\hline \multirow[b]{3}{*}{ Delivery methods } & \multicolumn{8}{|c|}{ Incubation time (h) } \\
\hline & \multicolumn{2}{|c|}{2} & \multicolumn{2}{|c|}{6} & \multicolumn{2}{|c|}{12} & \multicolumn{2}{|c|}{24} \\
\hline & Mean & SD & Mean & SD & Mean & SD & Mean & SD \\
\hline THF & $0 \cdot 13^{b}$ & 0.01 & $0.22^{b}$ & 0.02 & $0.10^{C}$ & 0.03 & $0.05^{\mathrm{b}}$ & 0.01 \\
\hline THF/BHT & $0.18^{a}$ & 0.01 & $0 \cdot 19^{a b}$ & 0.02 & $0.07^{\mathrm{c}}$ & 0.01 & $0.18^{\mathrm{a}}$ & 0.04 \\
\hline FBS & $0.16^{\mathrm{a}}$ & 0.02 & $0.23^{\mathrm{a}}$ & 0.01 & $0.38^{a}$ & 0.03 & $0.22^{a}$ & 0.08 \\
\hline$M-\beta-C D$ & - & & - & & $0.22^{\mathrm{b}}$ & 0.05 & - & \\
\hline
\end{tabular}

a,b,c Mean values within a column with unlike superscript letters were significantly different $(P<0.05)$.

delivered by FBS was significantly higher $(P<0 \cdot 05)$ than that delivered by THF, THF/BHT and M- $\beta-\mathrm{CD}$ (by 91,54 and $46 \%$, respectively) (Table 1), while the uptake in PC-3 cells delivered by FBS was significantly higher $(P<0.05)$ than that delivered by THF, THF/BHT and M- $\beta$-CD (by 280, 443 and $73 \%$, respectively) (Table 2). Regardless of the delivery vehicle, the lycopene uptake by DU145 cells at $12 \mathrm{~h}$ of incubation was higher than that by PC-3 cells, but at $24 \mathrm{~h}$ of incubation such differences had disappeared.

\section{Effects of lipoprotein on lycopene uptake in fetal bovine serum}

Because lycopene has been suggested to be transported by lipoprotein in man (Cardinault et al. 2005; Palozza et al. 2006), we assumed that the lipoprotein fraction of FBS is responsible for the increased uptake efficiency of lycopene in FBS. To test this assumption we employed lipoprotein-deficient serum as the delivery vehicle for lycopene and incubated with DU145 cells in comparison with FBS, THF and THF/BHT as vehicle. Lycopene solubilized in THF was as mixable in the lipoprotein-deficient serum as it was in FBS. This lipoprotein-deficient serum-lycopene mixture was added to culture medium immediately, and we observed no apparent lycopene loss or detectable cytotoxicity in using this mixture (data not shown). After incubation for $12 \mathrm{~h}$, the uptake efficiency of lycopene delivered by lipoprotein-deficient serum (1.8 (SD 0.2) \%) was indeed significantly lower than that by FBS $(3.4(\operatorname{SD} 0.6) \%, P<0.05)$ and was not significantly different from that by THF or THF/BHT (1.8 (SD 0.9) and 2.2 (SD 0.6) \%, respectively) (Table 3). The present results strongly indicate that the lipoprotein fraction of FBS plays an important role in delivering lycopene to cells. The present results in lycopene are in accord with those in other carotenoids or in $\alpha$-tocopherol. For instance, Martin et al. (1997) have

Table 3. Effect of lipoprotein-deficient serum (DL-S) in comparison with fetal bovine serum (FBS), tetrahydrofuran (THF) and THF/butylated hydroxytoluene (BHT), as delivery vehicle on lycopene uptake in DU145 cells*

(Mean values and standard deviations)

\begin{tabular}{|c|c|c|c|c|}
\hline \multirow[b]{2}{*}{ Delivery methods } & \multicolumn{2}{|c|}{$\begin{array}{l}\text { Lycopene uptake } \\
\left(\mathrm{nmol} / 10^{6} \text { cells) } \dagger\right.\end{array}$} & \multicolumn{2}{|c|}{$\begin{array}{c}\text { Uptake } \\
\text { efficiency (\%)‡ }\end{array}$} \\
\hline & Mean & SD & Mean & SD \\
\hline THF & $0.90^{\mathrm{b}}$ & 0.43 & $1 \cdot 8^{\mathrm{b}}$ & 0 \\
\hline THF/BHT & $1 \cdot 12^{b}$ & 0.32 & $2 \cdot 2^{\mathrm{b}}$ & \\
\hline FBS & $1.72^{a}$ & 0.29 & $3 \cdot 4^{\mathrm{a}}$ & 0.6 \\
\hline DL-S & $0.92^{b}$ & 0.05 & $1 \cdot 8^{\mathrm{b}}$ & 0.2 \\
\hline
\end{tabular}

${ }^{a, b}$ Mean values within a column with unlike superscript letters were significantly different $(P<0.05)$.

* Cells were incubated in a $10 \mathrm{~cm}$ Petri dish containing $5 \mathrm{ml}$ of a delivery vehicle for $12 \mathrm{~h}(n \geq 3)$.

tThe cellular uptake of lycopene is defined as the difference of total amounts of lycopene absorbed by the cells (determined at $37^{\circ} \mathrm{C}$ ) minus the amounts of lycopene adherent to the cell surface (determined at $4^{\circ} \mathrm{C}$ ).

$\ddagger$ The percentage uptake efficiency of lycopene was calculated by the formula: $\left[\left(\mathrm{nmol}\right.\right.$ lycopene $/ 10^{6}$ cells $) /(\mathrm{nmol}$ lycopene/dish $\left.) \times 100\right]$ (see Methods). 
reported that lipoproteins represent a stable vehicle for delivery of $\beta$-carotene and $\alpha$-tocopherol to HepG2 human liver cells. Interestingly, Williams et al. (2000) have shown that $\beta$-carotene-enriched serum obtained from an Angus steer fed $200 \mathrm{mg}$ $\beta$-carotene for 1 week provides a stable and physiological approach to carotenoid treatment of cells in culture.

\section{Conclusions}

The present study has demonstrated that the use of FBS for delivering lycopene into the two prostate cancer cell lines is superior to the use of THF, THF/BHT, M- $\beta-C D$ and micelles. The present results further indicate that the lipoprotein of FBS is likely responsible for the improved stability and cellular uptake of lycopene. Although lycopene delivered in FBS is only relatively stable (65 and $50 \%$ remaining at 9 and $12 \mathrm{~h}$ of incubation), this delivery vehicle represents a simple and useful system for investigating the physiological and toxicological properties of lycopene. It remains to be investigated as to whether this FBS delivery method for lycopene is suitable for in vitro studies in cell lines other than the prostate cancer cells.

\section{Acknowledgements}

This research was supported by grants (NSC-92-2320-B005003) from the National Science Council (Republic of China).

\section{References}

Bertram JS, Pung A, Churley M, Kappock TJ 4th, Wilkins LR \& Cooney RV (1991) Diverse carotenoids protect against chemically induced neoplastic transformation. Carcinogenesis 12, 671-678.

Bramley PM (2000) Is lycopene beneficial to human health? Phytochemistry 54, 233-236.

Cardinault N, Abalain JH, Sairafi B, Coudray C, Grolier P, Rambeau M, Carre JL, Mazur A \& Rock E (2005) Lycopene but not lutein nor zeaxanthin decreases in serum and lipoproteins in age-related macular degeneration patients. Clin Chim Acta 357, 34-42.

Clinton SK (1998) Lycopene: chemistry, biology, and implications for human health and disease. Nutr Rev 56, 35-51.

Conney RV, Kappock TJ, Pung A \& Bertram JS (1993) Solubilization, cellular uptake and activity of beta-carotene and other carotenoids as inhibitors of neoplastic transformation in cultured cells. Methods Enzymol 214, 55-68.

Da Violante G, Zerrouk N, Richard I, Provot G, Chaumeil JC \& Arnaud P (2002) Evaluation of the cytotoxicity effect of dimethyl sulfoxide (DMSO) on Caco2/TC7 colon tumor cell cultures. Biol Pharm Bull 25, 1600-1603.

Gamer AO, Jaeckh R, Leibold E, Kaufmann W, Gembardt C, Bahnemann R \& van Ravenzwaay B (2002) Investigations on cell proliferation and enzyme induction in male rat kidney and female mouse liver caused by tetrahydrofuran. Toxicol Sci 70, 140-149.

Garrett DA, Failla ML, Sarama RJ \& Craft N (1999) Accumulation and retention of micellar beta-carotene and lutein by Caco-2 human intestinal cells. J Nutr Biochem 10, 573-581.

Gross MD, Bishop TD, Belcher JD \& Jacobs DR Jr (1997) Solubilization of beta-carotene in culture media. Nutr Cancer 27, $174-176$.

Halliwell B (2003) Oxidative stress in cell culture: an under-appreciated problem? FEBS Lett 540, 3-6.

Huang CS, Fan YE, Lin CY \& Hu ML (2007) Lycopene inhibits matrix metalloproteinase-9 expression and down-regulates the binding activity of nuclear factor $\mathrm{\kappa B}$ and stimulatory protein 1 . $J$ Nutr Biochem Published online. PMID: 17049831.

Huang CS, Shih MK, Chuang CH \& Hu ML (2005) Lycopene inhibits cell migration and invasion and upregulates $\mathrm{nm} 23-\mathrm{H} 1$ in a highly invasive hepatocarcinogma, SK-Hep-1 cells. $J$ Nutr 135, 2119-2123.

Hurst JS, Contreras JE, Siems WG \& Van Kuijk FJ (2004) Oxidation of carotenoids by heat and tobacco smoke. Biofactors 20, 23-35.

Kotake-Nara E, Kushiro M, Zhang H, Sugawara T, Miyashita K \& Nagao A (2001) Carotenoids affect proliferation of human prostate cancer cells. J Nutr 131, 3303-3306.

Kristal AR \& Cohen JH (2000) Invited Commentary: tomatoes, lycopene, and prostate cancer. How strong is the evidence? Am J Epidemiol 151, 124-127.

Lancrajan I, Diehl HA, Socaciu C, Engelke M \& Zorn-Kruppa M (2001) Carotenoid incorporation into natural membranes from artificial carriers: liposomes and beta-cyclodextrins. Chem Phys Lipids 112, $1-10$.

Martin KR, Failla ML \& Smith JC Jr (1996) Beta-carotene and lutein protect HepG2 human liver cells against oxidant-induced damage. J Nutr 126, 2098-2106.

Martin KR, Loo G \& Failla ML (1997) Human lipoproteins as a vehicle for the delivery of beta-carotene and alpha-tocopherol to HepG2 cells. Proc Soc Exp Biol Med 214, 367-373.

Martin KR, Wu D \& Meydani M (2000) The effect of carotenoids on the expression of cell surface adhesion molecules and binding of monocytes to human aortic endothelial cells. Atherosclerosis 150, $265-274$

O'Sullivan SM, Woods JA \& O'Brien NM (2004) Use of Tween 40 and Tween 80 to deliver a mixture of phytochemicals to human colonic adenocarcinoma cell (CaCo-2) monolayers. Br J Nutr 91, 757-764.

Palozza P, Muzzalupo R, Trombino S, Valdannini A \& Picci N (2006) Solubilization and stabilization of beta-carotene in niosomes: delivery to cultured cells. Chem Phys Lipids 139, 32-42.

Pfitzner I, Francz PI \& Biesalski HK (2000) Carotenoid: methyl-betacyclodextrin formulations: an improved method for supplementation of cultured cells. Biochim Biophys Acta 1474, 163-168.

Polyakov NE, Leshina TV, Konovalova TA, Hand EO \& Kispert LD (2004) Inclusion complexes of carotenoids with cyclodextrins: $1 \mathrm{H}$ NMR, EPR, and optical studies. Free Radic Biol Med 36, $872-880$

Rodriguez AM, Sastre S, Ribot J \& Palou A (2005) Beta-carotene uptake and metabolism in human lung bronchial epithelial cultured cells depending on delivery vehicle. Biochim Biophys Acta 1740, 132-138.

Rundhaug JE, Pung A, Read CM \& Bertram JS (1988) Uptake and metabolism of beta-carotene and retinal by $\mathrm{C} 3 \mathrm{H} / 10 \mathrm{~T} 1 / 2$ cells. Carcinogenesis 9, 1541-1545.

Shahrzad S, Cadenas E, Sevanian A \& Packer L (2002) Impact of water-dispersible beadlets as a vehicle for the delivery of carotenoids to cultured cells. Biofactors 16, 83-91.

Sies H \& Stahl W (2003) Non-nutritive bioactive constituents of plants: lycopene, lutein and zeaxanthin. Int J Vitam Nutr Res 73, 95-100.

Stahl W \& Sies H (1996) Lycopene: a biologically important carotenoid for humans? Arch Biochem Biophys 336, 1-9.

Stivala LA, Savio M, Cazzalini O, Pizzala R, Rehak L, Bianchi L, Vannini V \& Prosperi E (1996) Effect of beta-carotene on cell cycle progression of human fibroblasts. Carcinogenesis 17, $2395-2401$.

Tang L, Jin T, Zeng X \& Wang JS (2005) Lycopene inhibits the growth of human androgen-independent prostate cancer cells in vitro and in BALB/c nude mice. J Nutr 135, 287-290.

Vertzoni M, Kartezini T, Reppas C, Archontaki H \& Valsami G (2006) Solubilization and quantification of lycopene in aqueous media in the form of cyclodextrin binary systems. Int $J$ Pharm 309, $115-122$. 
Wang LX, Lu J, Du ZL, Li RX \& Wu DC (2004) UV-vis spectroscopic characterization of inclusion compounds of betacyclodextrin with lycopene. Guang Pu Xue Yu Guang Pu Fen Xi 24, 183-186.

Williams AW, Boileau TW, Clinton SK \& Erdman JW Jr (2000) $\beta$ Carotene stability and uptake by prostate cancer cells are dependent on delivery vehicle. Nutr Cancer 36, 185-190.
Xu X, Wang Y, Constantinou AI, Stacewicz-Sapuntzakis M, Bowen PE \& van Breemen RB (1999) Solubilization and stabilization of carotenoids using micelles: delivery of lycopene to cells in culture. Lipids 34, 1031-1036.

Yeh SL, Huang CS \& Hu ML (2005) Lycopene enhances UVAinduced DNA damage and expression of heme oxygenase-1 in cultured mouse embryo fibroblasts. Eur J Nutr 44, 365-370. 